Meta

Journal des traducteurs

Translators' Journal

\title{
Ata annual convention
}

\section{Vittorio Felaco}

Volume 27, numéro 3, septembre 1982

URI : https://id.erudit.org/iderudit/001914ar

DOI : https://doi.org/10.7202/001914ar

Aller au sommaire du numéro

Éditeur(s)

Les Presses de l'Université de Montréal

ISSN

0026-0452 (imprimé)

1492-1421 (numérique)

Découvrir la revue

Citer cette note

Felaco, V. (1982). Ata annual convention. Meta, 27(3), 351-351.

https://doi.org/10.7202/001914ar

Ce document est protégé par la loi sur le droit d'auteur. L’utilisation des services d'Érudit (y compris la reproduction) est assujettie à sa politique d'utilisation que vous pouvez consulter en ligne.

https://apropos.erudit.org/fr/usagers/politique-dutilisation/
Cet article est diffusé et préservé par Érudit.

Érudit est un consortium interuniversitaire sans but lucratif composé de l'Université de Montréal, l'Université Laval et l'Université du Québec à Montréal. Il a pour mission la promotion et la valorisation de la recherche. https://www.erudit.org/fr/ 


\section{ATA ANNUAL CONVENTION}

The 1982 National Convention of the American Translators Association will be October 21-25 at Stouffer's National Center Hotel in Arlington, Virginia. This year will feature new sessions on Japanese and Arabic. Information: American Translators Association, 109 Croton Avenue, Ossining, New York 10562; tel. (914) 941-1500. 